\title{
EXPERIMENTAL AND NUMERICAL RESEARCH OF MECHANICAL BEHAVIOUR OF TITANIUM ALLOY HIP IMPLANT
}

\author{
Katarina Čolić, Aleksandar Sedmak, Kaled Legweel, Miloš Milošević, Nenad Mitrović, Žarko Mišković, \\ Sergej Hloch
}

Original scientific paper Experimental and numerical research of mechanical behaviour of hip replacement implant is presented. Experimental analysis was based on standard methods for testing mechanical properties and application of Digital Image Correlation (DIC) technique, while the Finite Element Method (FEM) was used for numerical simulation. A hip prosthesis extracted from a patient after revision surgery was used as the specimen. An adapter for the implant testing was constructed to enable the condition of a proximally loosened stem. During FEM analysis, a solid model was made of the assembly. An analysis of presented results indicated good agreement of experimental and numerical research.

Keywords: biomedical implant; digital image correlation; finite element method; Ti-6Al-4V alloy

Eksperimentalno i numeričko istraživanje mehaničkog ponašanja umjetnog kuka od legure titana

Izvorni znanstveni članak

U ovom radu prikazano je eksperimentalno i numeričko istraživanje mehaničkog ponašanja umjetnog kuka od legure titana. Eksperimentalno istraživanje je bazirano na standardnim metodama ispitivanja mehaničkih svojstava i na primjeni tehnike digitalne korelacije slike, dok je metoda konačnih elemenata (MKE) primijenjena u numeričkim simulacijama. Umjetni kuk je izvađen iz pacijenta prilikom revizijske operacije kako bi se iskoristio kao uzorak za ispitvanja. Konstruiran je adapter za ispitivanje takvog uzorka kajo bi se dobili uvjeti što sličniji realnim. Za MKE analizu napravljen je model cijelog ispitivanog sklopa. Dobiveni rezultati ukazuju na dobru sukladnost eksperimentalnog i numeričkog istraživanja.

Ključne riječi: digitalna korelacija slike; metoda konačnih elemenata; Ti-6Al-4V legura; umjetni kuk

\section{Introduction}

Hip replacement is a surgical procedure in which parts of a hip joint are removed and replaced with prosthesis, most commonly made of titanium-based alloys, especially Ti-6Al-4V, [1]. Although great advances have been made in this field, brittle fracture is still one of major problems

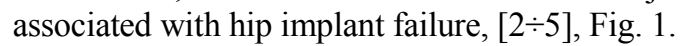

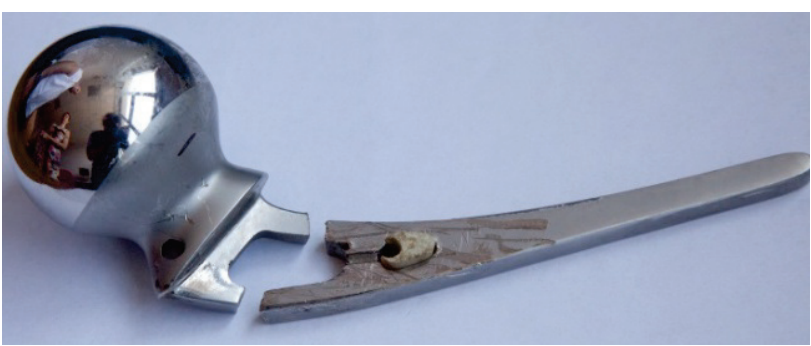

Figure 1 Hip prosthesis failure

In vivo, each prosthesis component is subjected to a different set of loads that is specific to the individual patient. In addition, the anchoring conditions vary depending on the patient's pre-existing diseases, design of prosthesis, quality of bone and surgical implantation techniques, $[1,6 \div 9]$. One should also keep in mind that scratches inevitably appear on implant surface, causing stress concentration, and providing location for crack initiation and propagation.

Therefore, despite strict regulation, hip implant failures still occur. Common causes are overloading and cracking, static or dynamic. Typical appearance of failure surface is given in Fig. 2, indicating relatively low toughness.

The main goal of this research was to examine hip implants, both experimentally and numerically, considering different forces acting on the prosthesis.
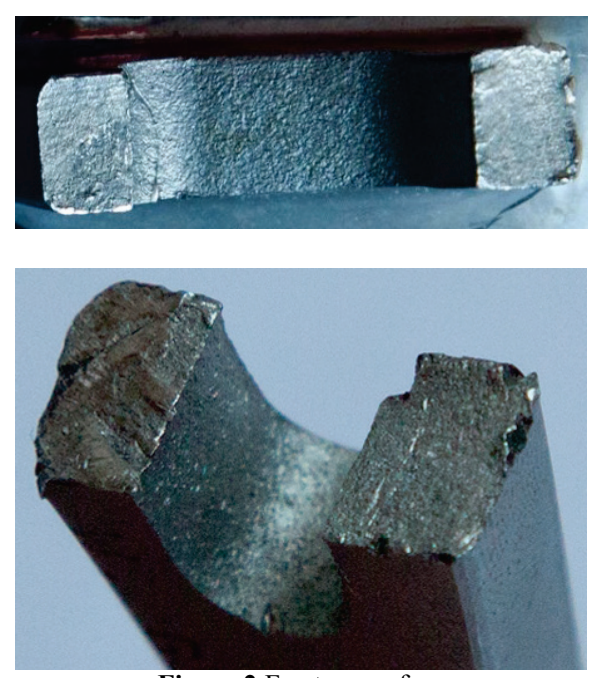

Figure 2 Fracture surface

\section{Experimental methodology}

The human hip is a ball and socket joint, enabling movement in all directions. To accomplish this, a hip implant is composed of two sections, femoral head and femoral stem. During walking and jogging, the forces acting across the hip joint are several times higher than the body weight, [10]. The loads depend on the walking speed and the weight of the subject.

Throughout normal activity there are a variety of loads acting on the femoral stem and the acetabulum. The femoral stem is a loaded column, and the loads applied to it can be resolved into orthogonal loads acting along vertical, mediolateral, and anteroposterior axes, [10, 11]. Despite the progress in design and testing, fatigue fractures of hip stems still happen. The ISO 7206 standard 
defines a laboratory test for determining the endurance properties of femoral components of hip prostheses, [12]. The current ISO 7206 standard defines that the load should be applied at an angle of $10^{\circ}$ in adduction to the stem axis, Fig. 3.

Furthermore, test conditions are based on the conservative assumption that the stem becomes unsupported proximally, remaining restrained at $80 \mathrm{~mm}$ from the centre of the head of the prosthesis, $[8 \div 10]$. To analyse the mechanical behaviour of prosthesis, static testing was performed, based on the ISO 7206 standard, Fig. 3, with some modifications, as explained later.

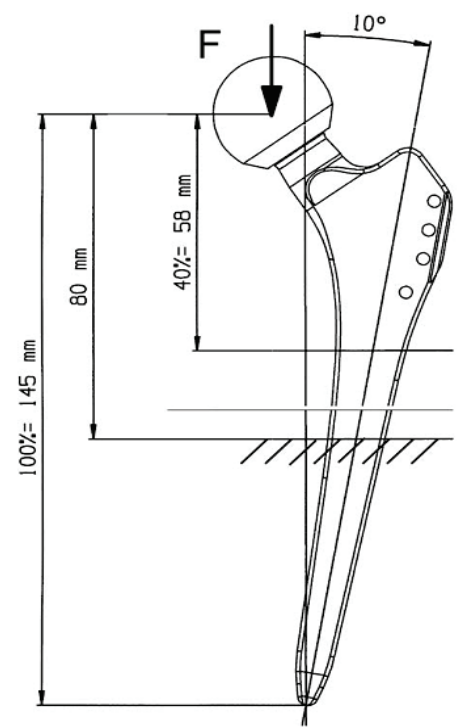

Figure 3 ISO fatigue test arrangement for hip stems

The force on an implant during normal walking is cca $2,3 \mathrm{kN}$ for a person of average weight $(830 \mathrm{~N}),[10,13]$. However, as the relevant load one should take into account the worst-case scenario - falling over an obstacle (stumbling), which corresponds to the force $6 \mathrm{kN}$ for a person of average weight, $[10,13]$.

To perform the experiment, an adapter to constrain the implant was constructed and used with the HB250 testing machine. During pre-testing research, a solid model of adapter was made, as shown in Fig. 4.

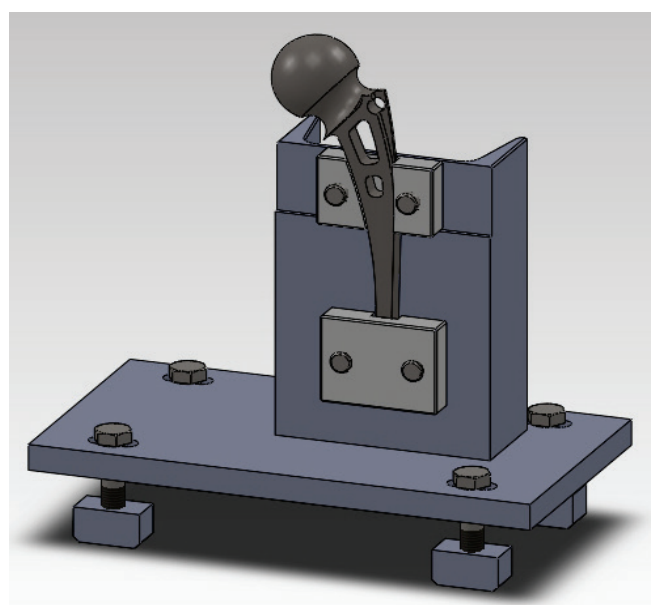

Figure 4 Solid model of testing arrangement

This test arrangement was developed to model a proximally loosened hip stem. Experiments were performed using the servo hydraulic testing machine ZWICK ROELL HB250. Experimental testing arrangement for titanium alloy implant is presented in Fig. 5, indicting somewhat different geometry in respect to the ISO 7206 standard, which was acceptable because the aim of this research was not to test endurance properties. Namely, the main aim of the experimental research was to determine correlation between load and displacement (vertical movement of loading cell, Fig. 5) and to compare results with numerical ones. Another important aspect of the experimental research was to perform static testing above the yielding point, i.e. in the plastic strain range.

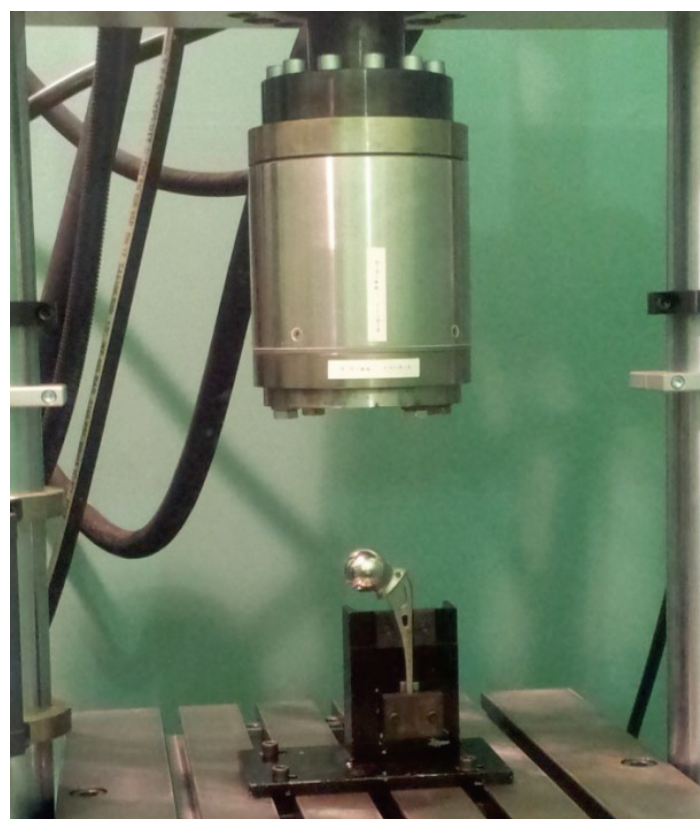

Figure 5 Servo-hydraulic dynamic and static material testing machine ZWICK ROELL HB250

Experimental analysis was based on 3D optical measuring system, so-called Digital Image Correlation (DIC). This 3D system for experimental analysis is useful in analysing structural integrity and determining properties of materials, $[13 \div 18]$. The method is also suitable for analysis of irregular object geometries made of various materials, as is often the case in biomedical applications. $[2,19,20]$.

The experimental system for digital image correlation uses two matched digital cameras that provide a synchronized stereo view of the specimen. It also includes the stand that provides stability of the sensors, an image recording and power control unit, and the data processing system, [16].

\section{Experimental results}

Artificial hip prosthesis with a conical stem and a spherical femoral head, Fig. 6, removed during revision surgery, was used for testing. The femoral head was made of cobalt-chromium alloy, while the stem component was made of Ti-6Al-4V alloy by casting.

The appearance of hip implant after simple static testing is shown in Fig. 7, indicating large plastic strains. 


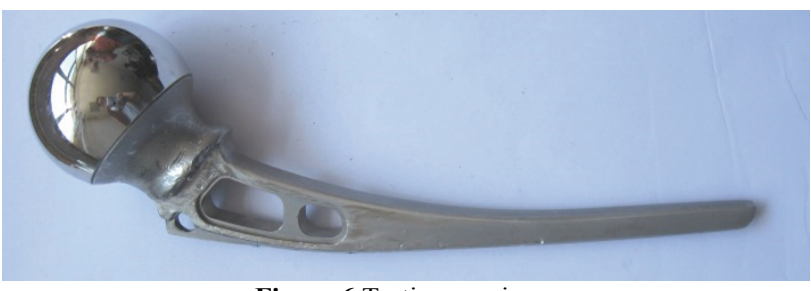

Figure 6 Testing specimen

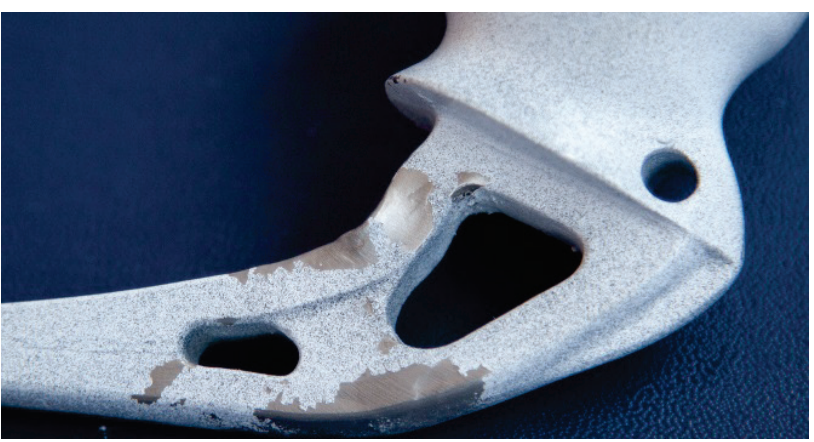

Figure 7 Plastic strains after static testing of hip implant

The force vs. displacement (vertical movement of the loading cell) diagram in Fig. 8 indicates $7,7 \mathrm{kN}$ as the maximum force before the occurrence of plastic straining, i.e. the yielding point. The maximum force during this experiment was cca $9 \mathrm{kN}$, as shown in Fig. 8.

Having in mind the basic mechanical properties of Ti6Al4V alloy, Yield Strength $780 \mathrm{MPa}$, Tensile Strength $860 \mathrm{MPa}$, Young's modulus $120 \mathrm{GPa}$ and Poisson's ratio 0,3 [13], one can correlate Yield Strength with the force $7,7 \mathrm{kN}$, which represents the loading at yielding initiation. This sets the upper limit for linear elastic behaviour of the hip implant made of Ti6Al4V alloy, which is used in this research.

Results obtained by using DIC technique, for the load $6 \mathrm{kN}$, are shown in Fig. 9, for strain distribution, as well as in Fig. 10 for displacement distribution. One should notice that data in Fig. 9 is valid only for the stem, because only this portion of specimen was prepared for measuring. Therefore, one should take as relevant only the strains obtained in the stem, being at maximum $(0,5$ $\%$ ) approximately in the region which is typical for hip implant failure, as shown in Fig. 1. The corresponding level of stress is $600 \mathrm{MPa}$.
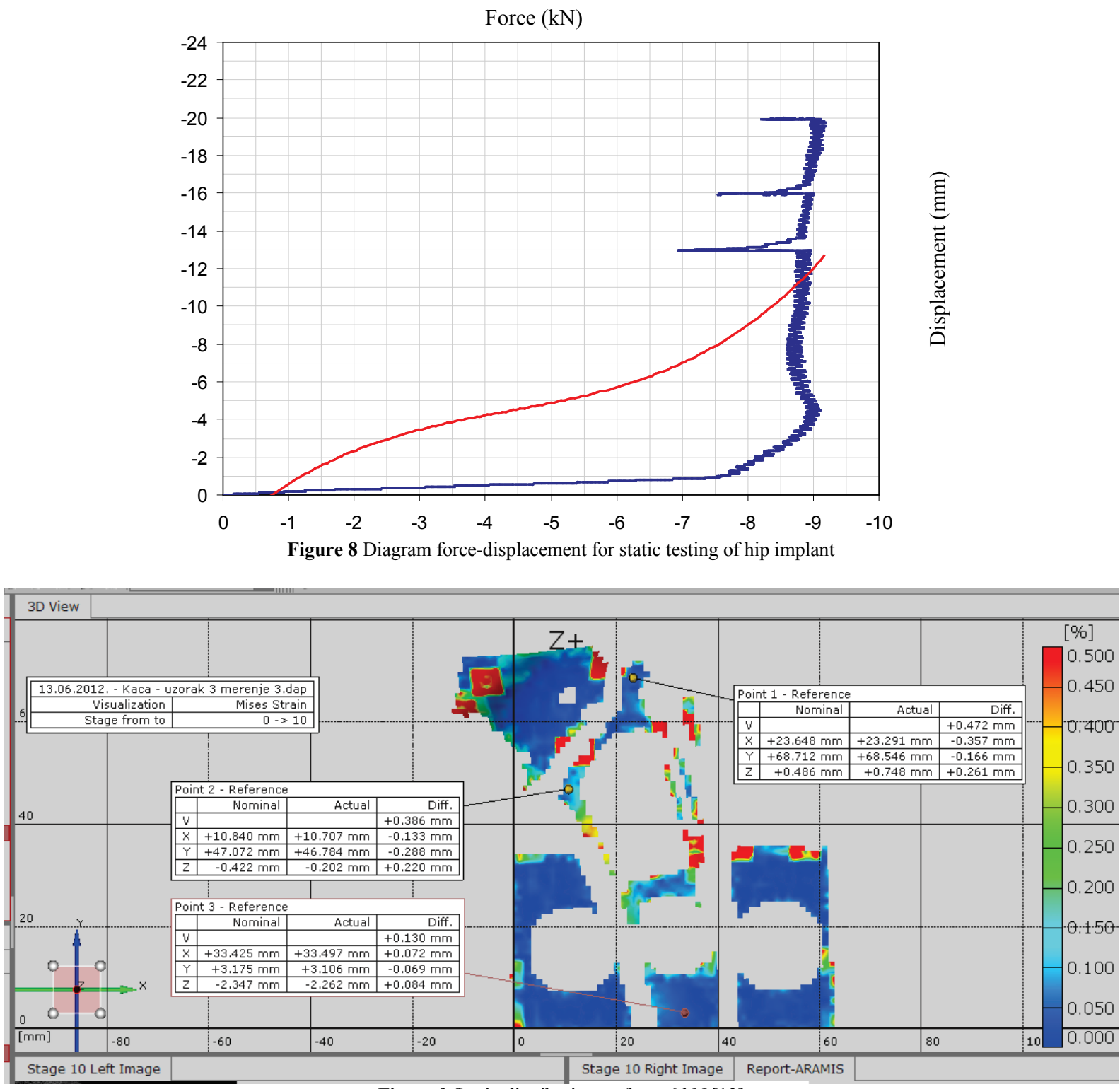

Figure 9 Strain distributions - force $6 \mathrm{kN}$ [13] 


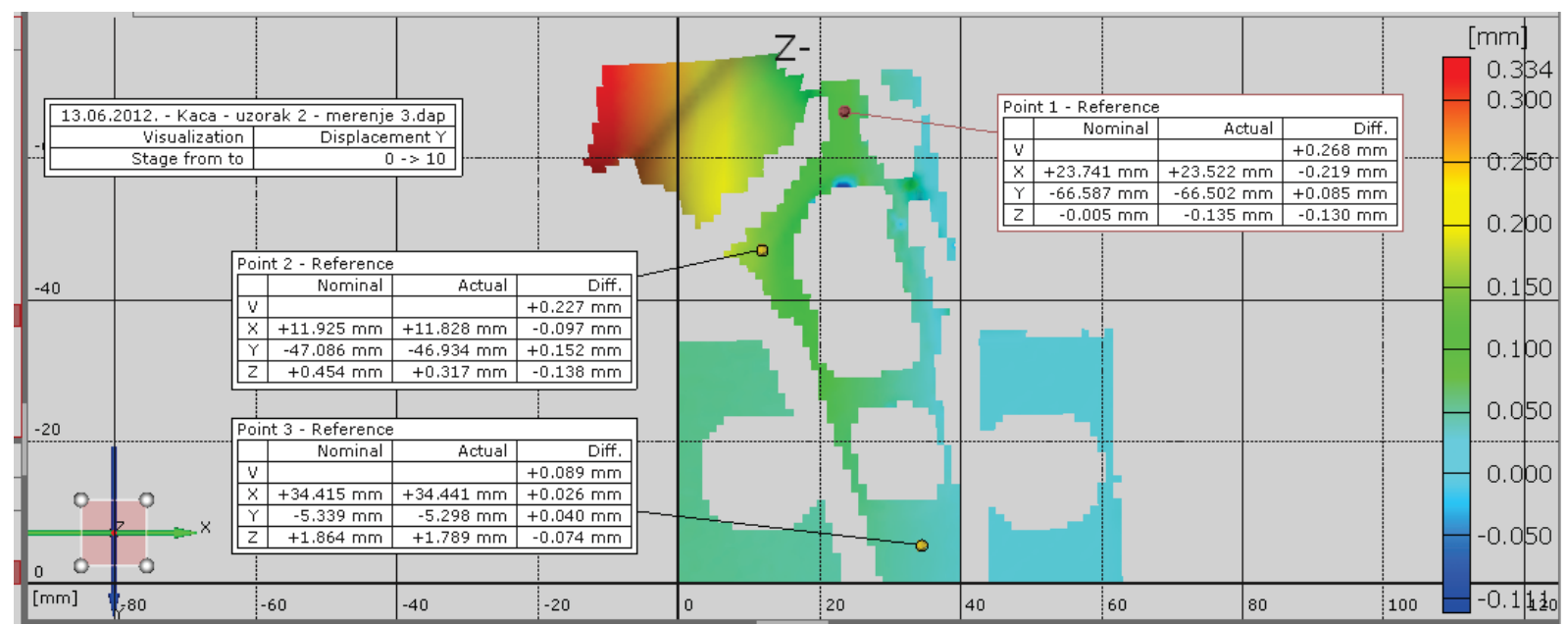

Figure 10 Displacement distributions - force $6 \mathrm{kN}$ [13]

\section{Numerical analysis}

The Finite Element Method has been applied to obtain linear elastic stress distribution in hip implant, loaded in the same way as during the experiment, with force of $6 \mathrm{kN}$. The mesh is generated so that problem is simulated as realistic as possible. Therefore, the adapter system has been modelled as well, following the solid model shown in Fig. 4. The finite element mesh is shown in Fig. 11.

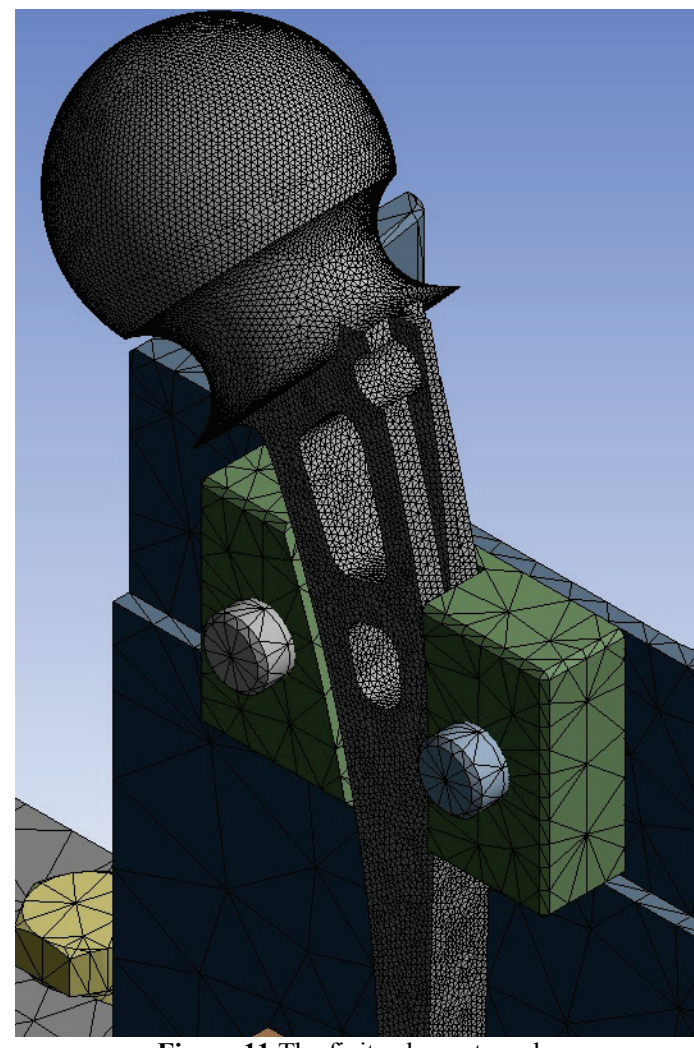

Figure 11 The finite element mesh

Stress distribution obtained by applying such a model is shown in Fig. 12. The maximum equivalent stress is still in the linear elastic range $(698 \mathrm{MPa})$, enabling simple calculation of the equivalent strain $(698 \mathrm{MPa} / 120 \mathrm{GPa}=$ $0,0058=0,58 \%$ ). This is in relatively good agreement with the experimental results, obtained by DIC, shown in Fig. $9(0,5 \%$, indicated by red colour $)$. Also the location of maximum stress/strain is in good agreement (compare
Figs. 9 and 12), as well as in good agreement with the typical fracture location, as seen in Fig. 1.

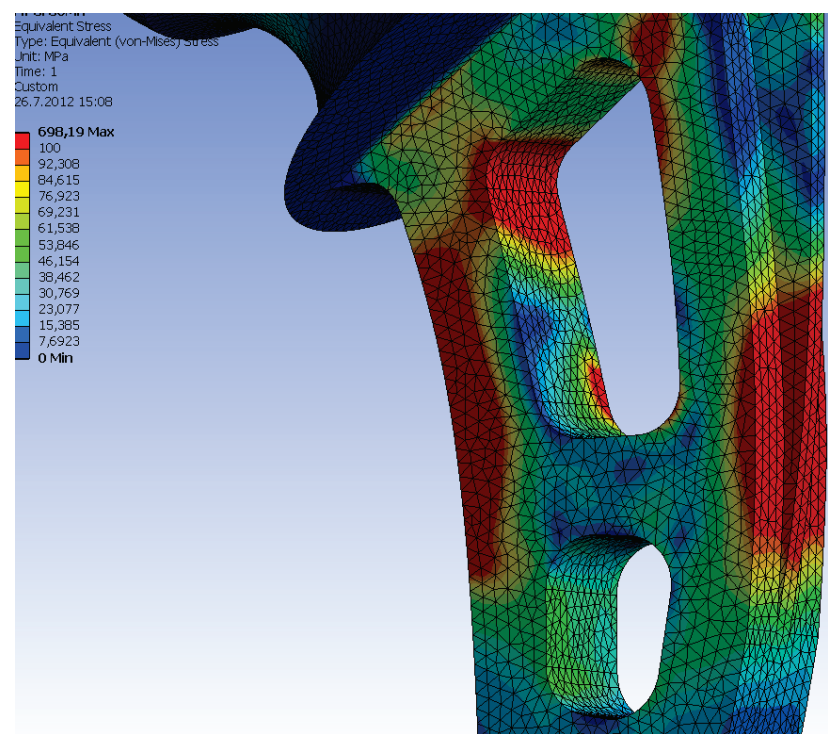

Figure 12 Stress distribution obtained by the FEM

Finally, if one takes into account yielding point as recorded during tensile testing, which means that stress level $780 \mathrm{MPa}$ is reached by applying force $7,7 \mathrm{kN}$, it is clear that DIC measurement provides better agreement (stress $600 \mathrm{MPa}$ - force $6 \mathrm{kN}$ ) than FEM (stress $698 \mathrm{MPa}$ - force $6 \mathrm{kN}$ ). Possible cause of higher stresses in FEM is modelling of geometry in critical areas.

\section{Conclusions}

The results of this study show that understanding of mechanical loading and behaviour of a hip implant is very important. Based on the results of experimental and numerical research, one can conclude the following:

- Behaviour of hip implant under $6 \mathrm{kN}$ force, corresponding to the worst case scenario (stumbling), is linear elastic.

- Experimental (DIC) and numerical (FEM) results are in good mutual agreement, difference being cca $15 \%$.

- Both experimental and numerical simulation of testing of hip implant provide sound basis for further research, since the results are in good agreement with the real ones, being in almost perfect match for DIC measu- 
rement, whereas FEM results predict cca $15 \%$ larger stresses.

\section{Acknowledgements}

The research work is funded by the support of the Ministry of Education and Science of the Republic of Serbia - Contract grants: TR 35040.

Note: This paper is extended and improved version of the paper "Design aspects of fracture behaviour of Titanium artificial hip implant" presented at the Int. Conf. TEAM 2013, in Presov, Slovakia, [21].

\section{References}

[1] Katz, J. N. Total joint replacement in osteoarthritis. // Best Practice \& Research Clinical Rheumatology. 20, 1(2006), pp. 145-153. DOI: 10.1016/j.berh.2005.09.003

[2] Legweel, K.; Sedmak, A.; Čolić, K.; Burzić, Z.; Gubeljak, L. Elastic-Plastic Fracture Behaviour of Multiphase Alloy MP35N. // Structural Integrity and Life. 15, 3(2015), pp. 163-166.

[3] Sedmak, A.; Čolić, K.; Burzić, Z.; Tadić, S. Structural Integrity Assessment of Hip Implant Made of CobaltChromium Multiphase Alloy. // Structural Integrity and Life. 10, 2(2010), pp. 161-164.

[4] Paliwal, M.; Allan, D. G.; Filip, P. Failure analysis of three uncemented titanium-alloy modular total hip stems. // Engineering Failure Analysis. 17, 5(2010), pp. 1230-1238. DOI: 10.1016/j.engfailanal.2010.02.011

[5] Chao J.; Lopez V. Failure analysis of a Ti6Al4V cementless HIP prosthesis. // Engineering Failure Analysis. 14(2007), pp. 822-830. DOI: 10.1016/j.engfailanal.2006.11.003

[6] Sargeant, A.; Goswami, T. Hip implants: Paper V. Physiological effects. // Materials \& Design. 27, 4(2006), pp. 287-307. DOI: 10.1016/j.matdes.2004.10.028

[7] Chimento, G. F.; Sculco, T. P. Minimally Invasive Total Hip Arthroplasty. // Operative Techniques in Orthopaedics. 11, 4(2001), pp. 270-273. DOI: 10.1016/S1048 6666(01)80041-0

[8] Archibeck, M. J. et al. Cementless Total Hip Arthroplasty in Patients 50 Years or Younger. // The Journal of Arthroplasty. 21, 4(2006), pp. 476-483. DOl: 10.1016/j.arth.2005.08.011

[9] Griza, S. et al. Design aspects involved in a cemented THA stem failure case. // Engineering Failure Analysis. 16, 1(2009), pp. 512-520. DOI: 10.1016/j.engfailanal.2008.06.016

[10] Bergmann, G. et al. Hip contact forces and gait patterns from routine activities. // Jour. of Biomechanics. 34(2001), pp.859-871. DOI: 10.1016/S0021-9290(01)00040-9

[11] Hernandez-Rodriguez, M.; Ortega-Saenz, J. A.; ContrerasHernandez, G. R. Failure analysis of a total hip prosthesis implanted in active patient. // Journal of the Mechanical Behavior of Biomedical Materials. 3, (2010), pp. 619-622. DOI: 10.1016/j.jmbbm.2010.06.004

[12] ISO 7206/4:2002. Determination of endurance properties of stemmed femoral components with application of torsion, Implants for surgery - partial and total hip joint prostheses.

[13] Colic, K. Fracture Behaviour Analysis of Artificial Hip Biomaterials (in Serbian). University of Belgrade, D.Sc. thesis, 2012

[14] Colic, K.; Sedmak, A.; Gubeljak, N.; Burzic, M.; Petronic, S. Experimental analysis of fracture behavior of stainless steel used for biomedical applications. // Structural Integrity and Life. 12, 1(2012.), pp. 59-63.

[15] Sedmak, A.; Milošević, M.; Mitrović, N.; Petrović, A.; Maneski, T. Digital Image Correlation in Experimental
Mechanical Analysis. // Structural Integrity and Life. 12, 1(2012), pp. 39-42.

[16] Gubeljak, N. Application of Stereometric Measurement on Structural Integrity. // Structural Integrity and Life. 6, 12(2006), pp. 65-74.

[17] Roncevic, B.; Bakic, A.; Kodvanj, J. Numerical and experimental analysis of a frictionless receding contact between cylindrical indenter, layer and substrate. // Transactions of FAMENA. 40, 2(2016), pp. 1-18. DOl: 10.21278/TOF.40201

[18] Wang, D. Z.; Mottershead, J. E. Measurement Precision and Spatial Resolution with Kriging Digital Image Correlation. // Strojniski vestnik-Journal of Mechanical Engineering. 62, 7-8(2016), pp. 419-429. DOI: 10.5545/svjme.2016.3736

[19] Zhang, D.; Arola, D. Applications of digital image correlation to biological tissues. // Journal of Biomedical Optics. 9, 4(2004), pp. 691-699. DOI: 10.1117/1.1753270

[20] Sztefek, P. et al. Using digital image correlation to determine bone surface strains during loading and after adaption of the mouse tibia. // Journal of Biomechanics. 43(2010), pp. 599-605. DOI: 10.1016/j.jbiomech.2009.10.042

[21] Colic, K.; Sedmak, A.; Gubeljak, N.; Hloch, S.; Veg, A. Design aspects of fracture behaviour of Titanium artificial hip implant. // Proc. $5^{\text {th }}$ Int. Sci. and Expert Conference TEAM 2013, Presov, Slovakia, 2013, pp. 22-25.

\section{Authors' addresses}

\section{Katarina Čolić, PhD}

University of Belgrade, Innovation Center of Faculty of Mechanical Engineering, Kraljice Marije 16, 11000 Belgrade, Serbia kbojic@mas.bg.ac.rs

\section{Aleksandar Sedmak, PhD}

University of Belgrade,

Faculty of Mechanical Engineering,

Kraljice Marije 16, 11000 Belgrade, Serbia

asedmak@mas.bg.ac.rs

\section{Kaled Legweel, Ph.D. student}

University of Belgrade,

Faculty of Mechanical Engineering,

Kraljice Marije 16, 11000 Belgrade, Serbia

\section{Miloš Milošević, PhD}

University of Belgrade,

Innovation Center of Faculty of Mechanical Engineering,

Kraljice Marije 16, 11000 Belgrade, Serbia

mmilosevic@mas.bg.ac.rs

\section{Nenad Mitrović, PhD}

University of Belgrade,

Faculty of Mechanical Engineering,

Kraljice Marije 16, 11000 Belgrade, Serbia

nmitrovic@mas.bg.ac.rs

\section{Žarko Mišković, MSci}

University of Belgrade

Faculty of Mechanical Engineering,

Kraljice Marije 16, 11000 Belgrade, Serbia

zmiskovic@mas.bg.ac.rs

\section{Sergej Hloch, PhD}

Faculty of Manufacturing Technologies of Technical University of Kosice with seat in Presov,

Bayerova 1, 08001 Prešov, Slovak Republic

Institute of Geonics Academy of Science of Czech Republic, v.v.i., Studentska 1768, 70800 Ostrava-Poruba, Czech Republic hloch.sergej@gmail.com 